This item was submitted to Loughborough's Research Repository by the author.

Items in Figshare are protected by copyright, with all rights reserved, unless otherwise indicated.

\title{
Protein purification with nanoparticle-enhanced crystallisation
}

PLEASE CITE THE PUBLISHED VERSION

https://doi.org/10.1016/j.seppur.2020.117384

PUBLISHER

Elsevier B.V.

VERSION

AM (Accepted Manuscript)

PUBLISHER STATEMENT

This paper was accepted for publication in the journal Separation and Purification Technology and the definitive published version is available at https://doi.org/10.1016/j.seppur.2020.117384

\section{LICENCE}

CC BY-NC-ND 4.0

\section{REPOSITORY RECORD}

Cheng, Wenqian, Thomas N.H. Cheng, LF Khaw, Xiaoyu Liu, Huaiyu Yang, Jinbo Ouyang, and Jerry Y.Y. Heng. 2021. "Protein Purification with Nanoparticle-enhanced Crystallisation". Loughborough University. https://hdl.handle.net/2134/16803643.v1. 


\section{Protein purification with nanoparticle-enhanced crystallisation}

Wenqian Chen ${ }^{a}$, Thomas N. H. Cheng ${ }^{a}$, Liang Fa Khaw ${ }^{a}$, Xiaoyu Li ${ }^{a}$, Huaiyu Yang ${ }^{b}$, Jinbo Ouyang ${ }^{c}$, Jerry Y. Y. Heng ${ }^{a, *}$

${ }^{a}$ Department of Chemical Engineering, Imperial College London, London SW7 2AZ, UK

${ }^{b}$ Department of Chemical Engineering, Loughborough University, Leicestershire LE11 3TU, UK

'State Key Laboratory for Nuclear Resources and Environment, East China University of Technology, Nanchang 330013, P. R. China

*Corresponding author.

E-mail address: jerry.heng@imperial.ac.uk 


\begin{abstract}
In this study, silica nanoparticle was synthesised and used to promote lysozyme crystallisation effectively against high concentrations of protein impurity (bovine serum albumin (BSA); concentration $=25.0-50.0 \mathrm{mg} / \mathrm{mL}$ vs $5.0-25.0 \mathrm{mg} / \mathrm{mL}$ for lysozyme) at $1 \mathrm{~mL}$ scale, demonstrating that crystallisation is a viable and scalable protein purification technology with the aid of heterogeneous nucleants. The silica nanoparticle expedited the crystallisation of lysozyme through the enhancement of nucleation, significantly improving the process productivity. Furthermore, this study demonstrates the proper use of nanoparticle in terms of cycle time, as the improvement of productivity by silica nanoparticle has a monomodal peak shape over time.
\end{abstract}

\title{
Keywords:
}

Biopurification, protein crystallisation, silica nanoparticle, surface charge, adsorption 


\section{Introduction}

Therapeutic proteins such as insulin and monoclonal antibodies (mAb) provide effective treatments to a wide range of medical conditions and their demands have grown rapidly over the past two decades. For example, the global sale of mAb products almost doubled within five years between 2008 and 2013, reaching nearly $\$ 75$ billion, and is expected to increase further to $\$ 125$ billion by 2020 [1]. As the production scale of therapeutic proteins has a continuous growth into the foreseeable future due to the strong demand, the production bottleneck shifts to downstream as upstream innovation leads to higher product titer [2].

Although chromatography is the mainstream purification technology for therapeutic proteins because of high resolution and reliability [3-5], it has been widely accepted that chromatography is throughput limited and not the most efficient method for processing large quantity of proteins [6,7]. In addition, chromatography have problems such as the generation of large quantity of liquid waste, as well as protein aggregation and leaching from resin, which have detrimental effects on the protein quality $[8,9]$.

Alternative protein purification technologies such as crystallisation [10-15], precipitation [16], filtration [17-19] and extraction [20-25] have been developed to overcome these drawbacks of chromatography. Among these technologies, protein crystallisation is the most technically challenging option due to the difficulty of forming highly ordered structure with large flexible protein molecules $[26,27]$. However, crystallisation is also the most ideal option as it can significantly simplify the downstream process through the integration of purification and formulation, and achieve significant reduction in waste. Therapeutic proteins in the crystalline form have multiple advantages over its solution counterpart including higher stability, higher dosage concentration and better release control as demonstrated in cases of insulin, infliximab and trastuzumab [28-30].

Given the technical difficulty and high cost of protein, the literature on protein crystallisation as the purification process is limited [31]. In the context of therapeutic proteins, crystallisation is even more difficult due to the presence of biological impurities such as host cell protein, DNA and virus, among which host cell protein normally has the highest concentration and hence poses the greatest hindrance to the success of crystallisation [32].

Through the manipulation of size, shape, surface chemistry and pore size, different solid templates (i.e. heterogeneous nucleants) have been developed to effectively improve the success rate of protein crystallisation [33-40]. However, they are often used in small-scale studies that aim to obtain single crystals with high quality from purified protein solution instead of scale-up studies that aim to achieve the purification of protein against impurities $[41,42]$ due to various reasons including limited availability of target protein and denaturation of protein under agitation [43].

The current study is the first to address this knowledge gap by demonstrating the feasibility of using silica nanoparticle as a heterogeneous nucleant to promote the crystallisation of a model protein (i.e. lysozyme) against a model protein impurity (i.e. bovine serum albumin (BSA)) in scale-up experiments (volume $=1 \mathrm{~mL}$ ). BSA served as a suitable model protein impurity as it has adverse impacts on the crystallisation of lysozyme, successfully simulating the role of protein impurity (i.e. host cell proteins) for the industrial purification of recombinant protein [32]. The findings here serve as the convincing evidence that crystallisation is a competitive biopurification technology for industrial applications through the use of heterogeneous nucleants, whose physiochemical properties such as pore size and surface chemistry can be tuned to achieve biopurification for specific protein/impurity mixtures. 


\section{Materials and methods}

\subsection{Materials}

For the synthesis of silica nanoparticle, tetraethyl orthosilicate (TEOS) (98\%) was supplied by Sigma Aldrich (Gillingham, UK). Sodium hydroxide and ethanol $(\geq 99.8 \%)$ were supplied by VWR (Lutterworth, UK). De-ionised water was obtained from a PURELAB Chorus 1 water purification system (ELGA LabWater (High Wycombe, UK)).

For the characterisation of silica nanoparticle with scanning electron microscopy (SEM), carbon conductive adhesive tape was purchased from Agar Scientific (Stansted, UK).

For protein crystallisation, lysozyme ( $\geq 90 \%), \mathrm{BSA}(\geq 96 \%)$, sodium chloride and sodium acetate $(>99 \%)$ were purchased from Sigma Aldrich (Gillingham, UK). Acetic acid glacial (>99.7\%) was purchased from VWR (Lutterworth, UK). De-ionised water was obtained from the same water purification system mentioned above. Surfactant-free cellulose acetate membrane filter $(0.2 \mu \mathrm{m})$ was purchased from Sartorius (Goettingen, Germany).

All chemicals were used as received without any further purification. More details can be found in the Supporting Information.

\subsection{Synthesis and characterisation of silica nanoparticle}

The synthesis method was adopted from previous studies $[44,45]$. At $40{ }^{\circ} \mathrm{C}$ under stirring, TEOS (60 $\mathrm{mL}$ ) was added into a mixture of de-ionised water and ethanol ( $960 \mathrm{~mL} / 138 \mathrm{~mL}$ ) before the addition of $0.1 \mathrm{M} \mathrm{NaOH}(42 \mathrm{~mL})$. After being stirred overnight at the same temperature, the final mixture was centrifuged (6000 rpm, 10 minutes) for the recovery of silica nanoparticles. The recovered silica nanoparticles were dried at room temperature.

For SEM, silica nanoparticles were placed on the carbon conductive adhesive tape and coated with chromium (thickness $\sim 15 \mathrm{~nm}$ ) in a Q150T turbomolecular-pumped coating system (Quorum Technologies (Laughton, UK)) with the settings of sputter current $=120 \mathrm{~mA}$, tooling factor $=2.43$ and maximum sputtering time $=4$ minutes. The chromium-coated nanoparticles were analysed with a Leo Gemini 1525 SEM (Carl Zeiss (Oberkochen, Germany)) with an accelerating voltage of 5 kV.

\subsection{Protein crystallisation}

The preparation of sodium acetate buffer $(0.24 \mathrm{M})$ was done by dissolving anhydrous sodium acetate $(2.00 \mathrm{~g})$ in de-ionised water $(100 \mathrm{~mL})$ before the addition of acetic acid $(1 \mathrm{~mL})$. The $\mathrm{pH}$ and conductivity at room temperature were 4.8 and $16 \mathrm{mS}$ respectively. The sodium acetate buffer was filtered through a $0.2 \mu \mathrm{m}$ filter.

The preparation of precipitant (i.e. 1.4 M sodium chloride solution) was done by dissolving sodium chloride $(12.27 \mathrm{~g})$ in the sodium acetate buffer $(150 \mathrm{~mL})$ and the solution was filtered through a 0.2 $\mu \mathrm{m}$ filter. The $\mathrm{pH}$ and conductivity at room temperature were 4.5 and $108 \mathrm{mS}$ respectively.

The preparation of protein solution was done by dissolving the protein (lysozyme, BSA or mixture) in the sodium acetate buffer. For example, to prepare a lysozyme solution with target concentration of 
$50 \mathrm{mg} / \mathrm{mL}$, lysozyme (250 $\mathrm{mg}$ ) was dissolved in sodium acetate buffer $(5 \mathrm{~mL})$. Once lysozyme was fully dissolved, the solution was filtered through a $0.2 \mu \mathrm{m}$ filter.

For protein crystallisation without silica nanoparticle, the sodium chloride solution (i.e. precipitant) and the protein solution was mixed with a $1: 1(\mathrm{v} / \mathrm{v})$ ratio with gentle mixing using a $1 \mathrm{~mL}$ pipette. The final mixture $(1 \mathrm{~mL})$ was placed under static condition in the incubator, whose internal temperature was maintained at $25^{\circ} \mathrm{C}$.

For protein crystallisation with silica nanoparticle, the silica nanoparticle $(10 \mathrm{mg})$ was washed with the sodium acetate buffer $(1 \mathrm{~mL})$ under sonication for 30 seconds, centrifuged for one minute and the clear supernatant was removed carefully to minimise the loss of nanoparticles. This process was repeated five times to remove any residual chemicals from the synthesis of nanoparticle. A proteinprecipitant mixture $(1: 1, \mathrm{v} / \mathrm{v})(1 \mathrm{~mL})$ was added to the washed nanoparticle and the final mixture was gently rotated and tapped to disperse the nanoparticles and mix the nanoparticles with the proteinprecipitant mixture. The mixture was placed under static condition in the incubator, which was kept at $25^{\circ} \mathrm{C}$.

For monitoring the crystallisation process, the protein concentration in the system was determined by measuring the 280-nm absorbance with a NanoDrop 2000c microvolume UV-vis spectrophotometer (Thermo Fisher Scientific, USA) with a sample volume of $2 \mu \mathrm{L}$. The calibration curves of pure lysozyme, pure BSA and lysozyme in the presence of BSA (BSA concentration fixed at $25.0,37.5$ and $50.0 \mathrm{mg} / \mathrm{mL}$ ) can be found in the Supporting Information.

Before sampling for absorbance measurement, the mixture was rotated gently by hand to ensure sufficient mixing and $20 \mu \mathrm{L}$ of slurry was pipetted out and centrifuged (6000 rpm, 1 minute). The clear supernatant $(10 \mu \mathrm{L})$ was pipetted out for UV-vis measurement without any dilution $(2 \mu \mathrm{L}$ each time for five times). The bottom slurry was pipetted out and observed under a CX-41 bright field microscope (Olympus (Tokyo, Japan)) for crystals. 


\section{Results and discussion}

Under all the experimental conditions in this study, BSA remained in the dissolved state instead of proceeding to crystallisation as a previous study showed that BSA molecules had slightly repulsive protein-protein interactions at high salt concentration $([\mathrm{NaCl}]=0.7 \mathrm{M})$ and $\mathrm{pH}$ close to its isoelectric point (pl) (i.e. 4.6 vs 4.9) [46].

\subsection{Negative impact of protein impurity on crystallisation}

The scale-up experiments showed that BSA delayed the crystallisation of lysozyme, contradicting the previous studies, where trace amount of BSA appeared to promote the nucleation of lysozyme and resulted in significantly higher number of crystals $[47,48]$. As shown in Fig. 1a, pure lysozyme with an initial concentration of $15.0 \mathrm{mg} / \mathrm{mL}$ had a latent period of four days (i.e. protein concentration started to decrease in the protein/precipitant mixture and large quantity of crystals started to appear). In the presence of BSA (concentration $=25.0 \mathrm{mg} / \mathrm{mL}$ ), the latent period was doubled to eight days.

The impeded crystallisation kinetics led to a reduction in productivity (defined in section S4 of the Supporting Information). If the target recovery (defined in section S4 of the Supporting Information) is $40 \%$, BSA at $25.0 \mathrm{mg} / \mathrm{mL}$ would increase the cycle time significantly from 8 days to 12 days (Fig. 1 b) and reduce the productivity by $33 \%$. Further increase in the BSA concentration to $37.5 \mathrm{mg} / \mathrm{mL}$ and $50.0 \mathrm{mg} / \mathrm{mL}$ would increase the cycle time to 14 days and lower the productivity by $43 \%$.
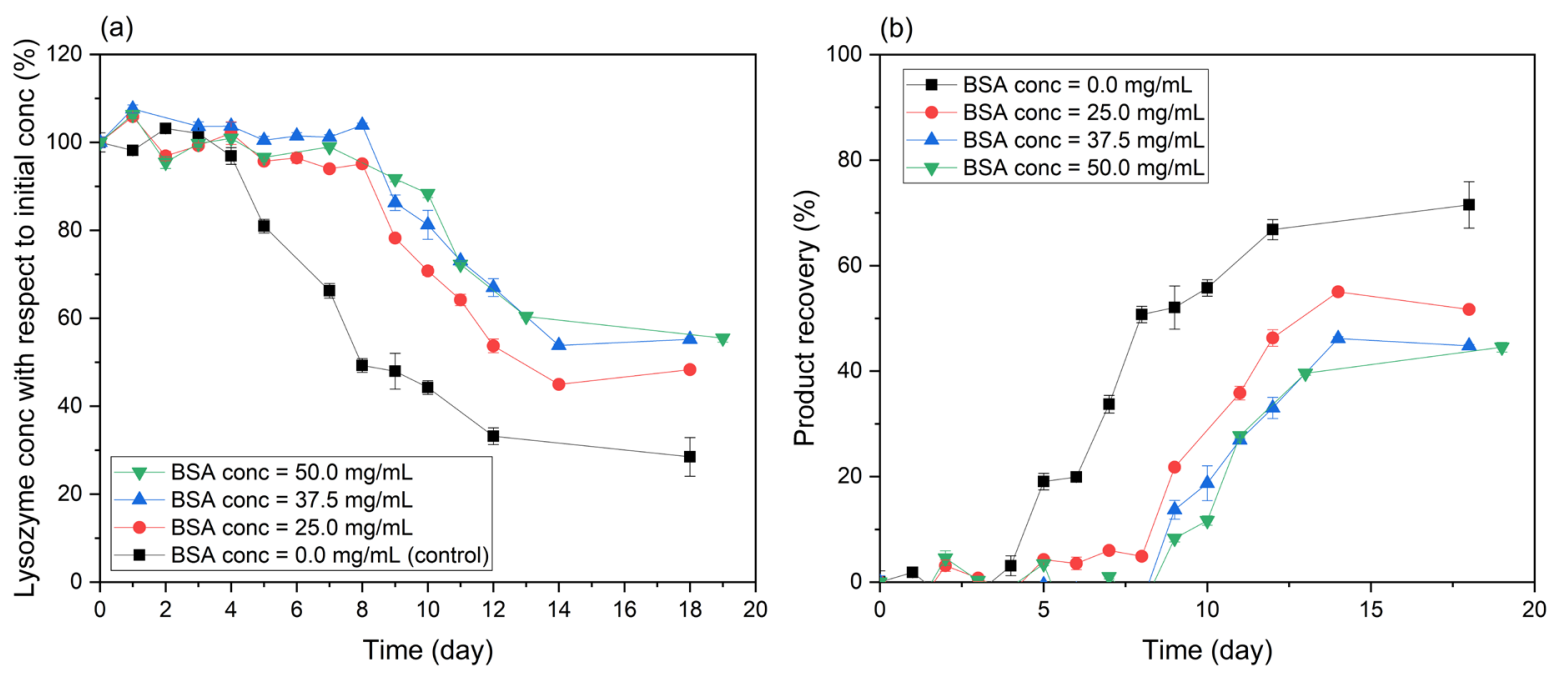

Fig. 1. Lysozyme crystallisation without silica nanoparticle with initial lysozyme concentration of 15.0 $\mathrm{mg} / \mathrm{mL}$ : (a) protein concentration over time and (b) product recovery over time.

The second negative impact of BSA is the reduction of lysozyme recovery at equilibrium due to the improvement of lysozyme solubility by BSA. Pure lysozyme at the current experimental conditions (i.e. room temperature, $\mathrm{pH}=4.6,[\mathrm{NaCl}]=0.7 \mathrm{M}$ ) had a solubility of $4.1 \pm 0.1 \mathrm{mg} / \mathrm{mL}$ (Fig. 2). The presence of BSA increased the lysozyme solubility to $6.2 \pm 0.0 \mathrm{mg} / \mathrm{mL}$ (BSA concentration $=25.0$ $\mathrm{mg} / \mathrm{mL}$ ), $8.3 \pm 0.0 \mathrm{mg} / \mathrm{mL}$ (BSA concentration $=37.5 \mathrm{mg} / \mathrm{mL}$ ) and $8.4 \pm 0.1 \mathrm{mg} / \mathrm{mL}$ (BSA concentration $=50.0 \mathrm{mg} / \mathrm{mL}$ ), leading to the reduction of product recovery at equilibrium from $71.5 \pm 4.4 \%$ (pure 
lysozyme) to $51.7 \pm 0.5 \%$ (BSA concentration $=25.0 \mathrm{mg} / \mathrm{mL}$ ), $44.8 \pm 0.3 \%$ (BSA concentration $=37.5$ $\mathrm{mg} / \mathrm{mL}$ ) and $44.5 \pm 0.9 \%$ (BSA concentration $=50.0 \mathrm{mg} / \mathrm{mL}$ ).

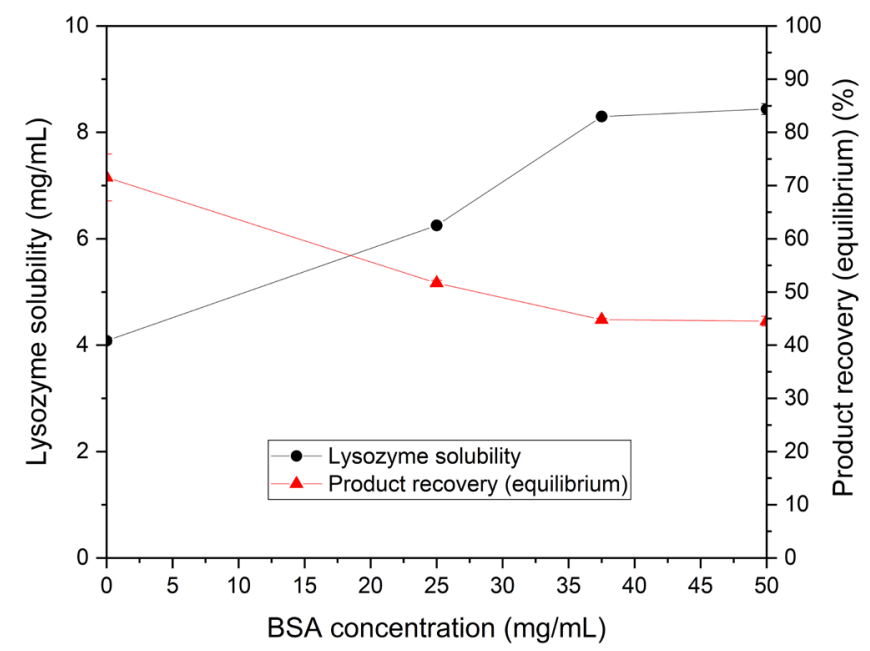

Fig. 2. Lysozyme solubility (black circle) and product recovery (red triangle) against BSA concentration for initial lysozyme concentration of $15.0 \mathrm{mg} / \mathrm{mL}$ without nanoparticle.

Being highly soluble and stable in water, albumin such as BSA is well-known for improving the solubility of a wide range of hydrophobic molecules and proteins such as fatty acids, sorbitol dehydrogenase, glucose oxidase and alcohol dehydrogenase etc by forming weak interactions [4952]. This study shows that BSA also increased the solubility of lysozyme, probably through weak interactions among the BSA and lysozyme molecules [46,53,54].

At the experimental $\mathrm{pH}$ of 4.6 , BSA molecules $(\mathrm{pl}=4.9)$ were relatively neutral, whereas lysozyme molecules $(\mathrm{pl}=11.1)$ were positively charged (Table 1$)$. Therefore, the weak interaction between BSA and lysozyme was most likely due to the interaction of BSA with the hydrophobic patches on the surface of lysozyme [55]. As a result, the BSA molecules shielded the lysozyme molecules from one another and reduced the frequency of contact, leading to a lower chance of subsequent agglomeration of lysozyme molecules to form the critical nuclei (Fig. 3).

Table 1

Properties of lysozyme, BSA and silica nanoparticle [56-58].

\begin{tabular}{lccc}
\hline & Lysozyme & BSA & Silica nanoparticle \\
\hline Molecular weight (kDa) & 14.6 & 68.0 & ---- \\
Dimension (nm) & $4.5 \times 3.0 \times 3.0$ & $4.0 \times 4.0 \times 14.0$ & 410 (diameter)* \\
Isoelectric point (pl) & 11.1 & 4.9 & 2.0 \\
Surface charge at experimental pH (4.6) & + & $+/-$ & - \\
& & &
\end{tabular}

*Measurement based on the SEM of silica nanoparticle (Fig. 5) 


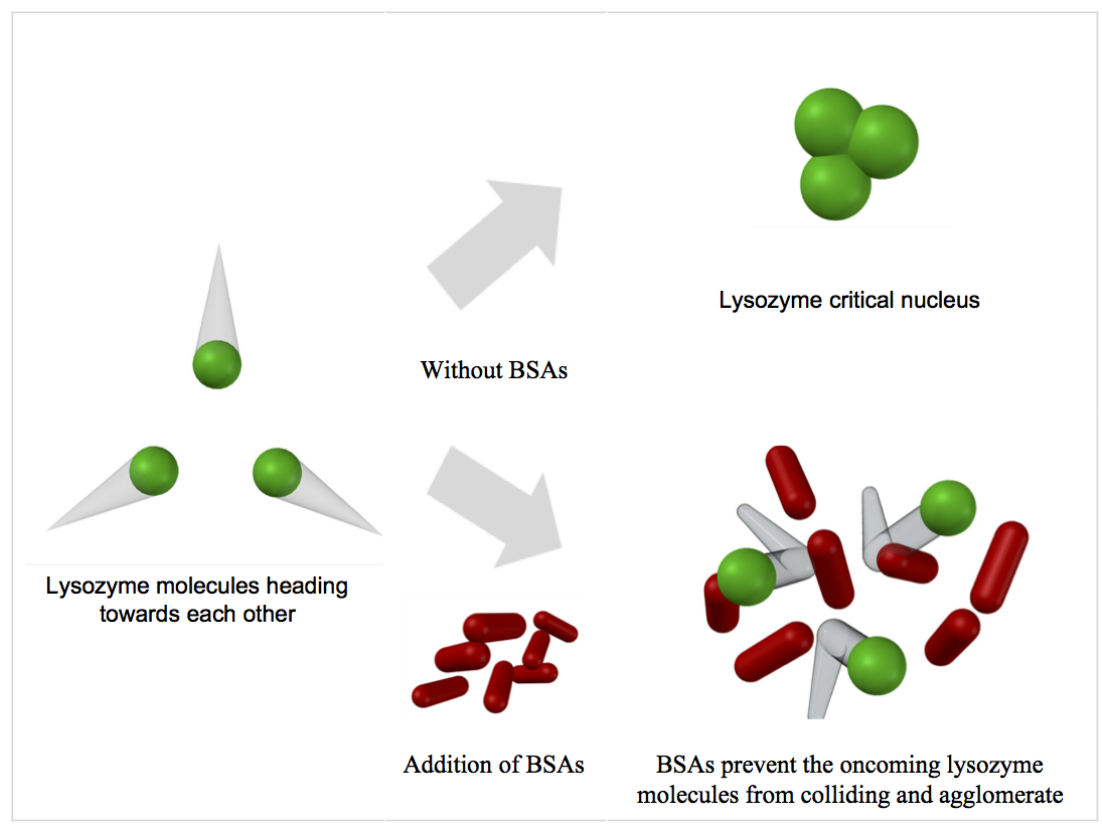

Fig. 3. Shielding effect of BSA (green and red spheres represent lysozyme and BSA molecules respectively).

The weak interaction between BSA and lysozyme was reflected by the shape of lysozyme crystals (section S3 of the Supporting Information). With the initial lysozyme concentration of $15.0 \mathrm{mg} / \mathrm{mL}$, the crystals remained predominantly tetragonal across the entire range of BSA concentration (Fig. 4), similar to a previous report [59]. This suggests that BSA was not incorporated into the lysozyme crystal, probably due to the significantly larger size of BSA $(4.0 \mathrm{~nm} \times 4.0 \mathrm{~nm} \times 14.0 \mathrm{~nm}$ vs $4.5 \mathrm{~nm} \times$ $3.0 \mathrm{~nm} \times 3.0 \mathrm{~nm}$ for lysozyme) (Table 1), unlike the case where lysozyme from a different source (i.e. turkey egg white) had observable effect on the aspect ratio of hen egg white lysozyme crystals due to the incorporation of this structurally similar protein impurity into the crystal [60].

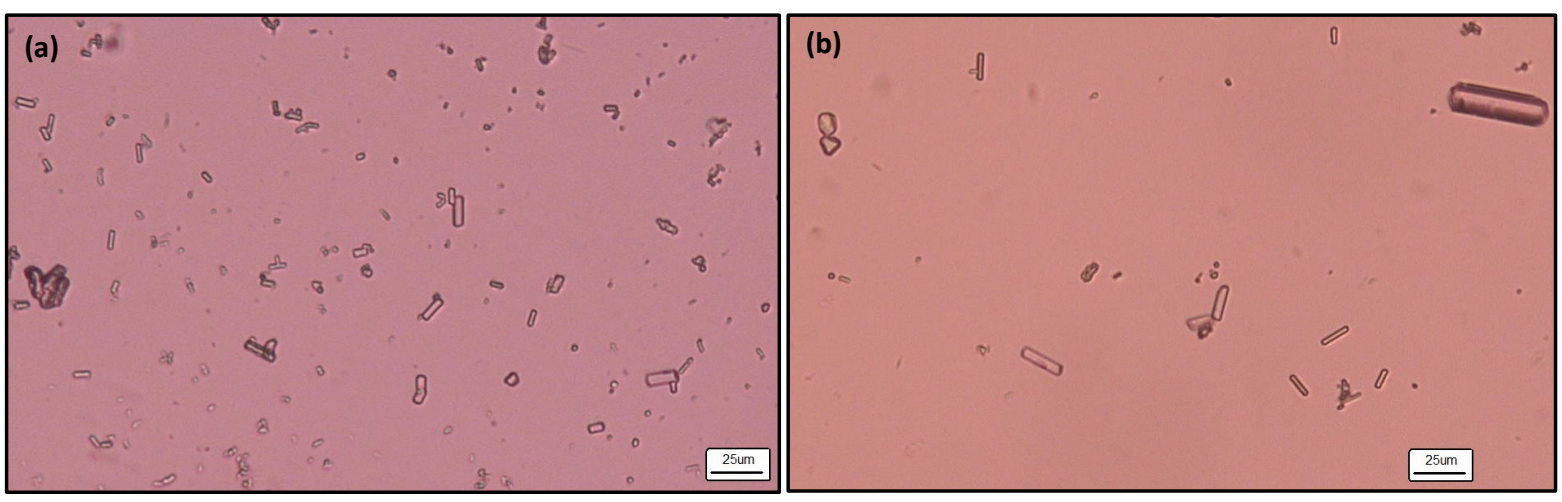

Fig. 4. Tetragonal shape of lysozyme crystals at (a) $B S A$ concentration $=0.0 \mathrm{mg} / \mathrm{mL}$ (i.e. pure lysozyme) and (b) BSA concentration $=50.0 \mathrm{mg} / \mathrm{mL}$ with the initial lysozyme concentration $=15.0$ $\mathrm{mg} / \mathrm{mL}$. 


\subsection{Mitigation of protein impurity with silica nanoparticle}

The spherical silica nanoparticles (diameter $=410 \pm 31 \mathrm{~nm}$ ) synthesised in this study were highly monodisperse in terms of size and shape (Fig. 5). These nanoparticles significantly enhanced crystallisation kinetics of lysozyme without affecting the solubility (Fig. 6). As a result, the presence of silica nanoparticles lowered the supersolubility line of lysozyme across the entire range of impurity (i.e. BSA) concentration (Fig. 7a), significantly improving the recovery of lysozyme in comparison with the control case (Fig. 7b).

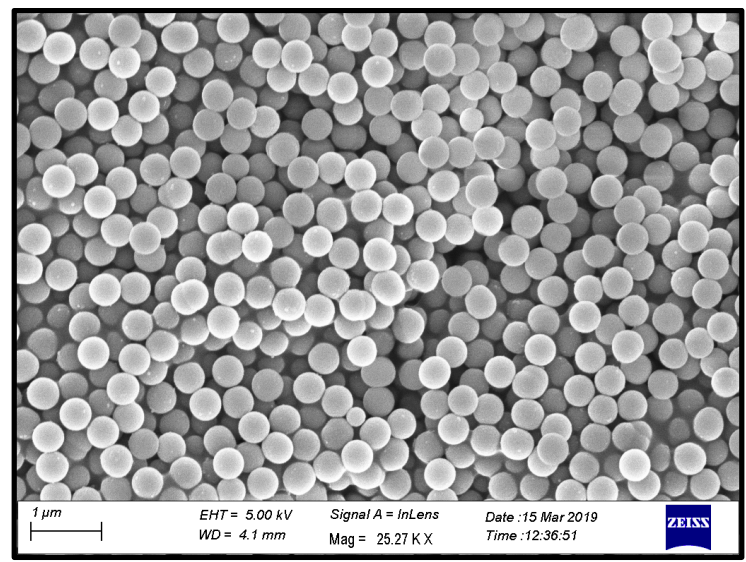

Fig. 5. SEM images of silica nanoparticle.

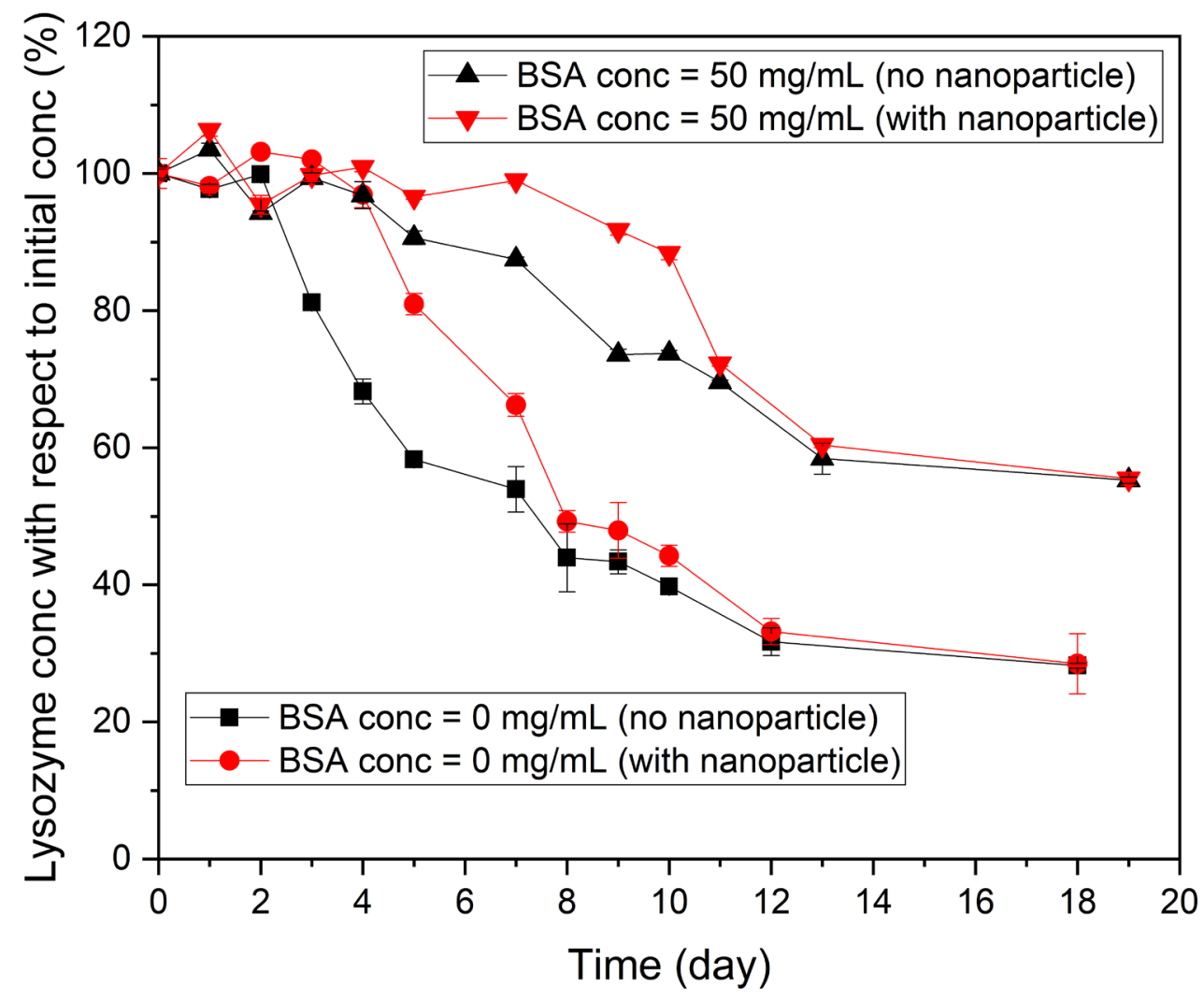

Fig. 6. Lysozyme crystallisation with silica nanoparticle with initial lysozyme concentration of 15.0 $\mathrm{mg} / \mathrm{mL}$ and BSA concentration of $0 \mathrm{mg} / \mathrm{mL}$ (i.e. pure lysozyme) and $50 \mathrm{mg} / \mathrm{mL}$. 
(a)

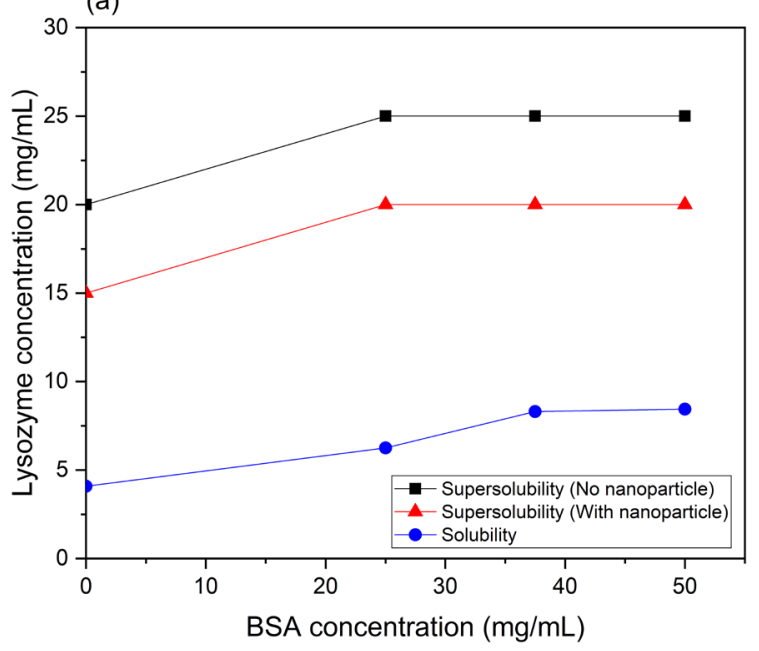

(b)

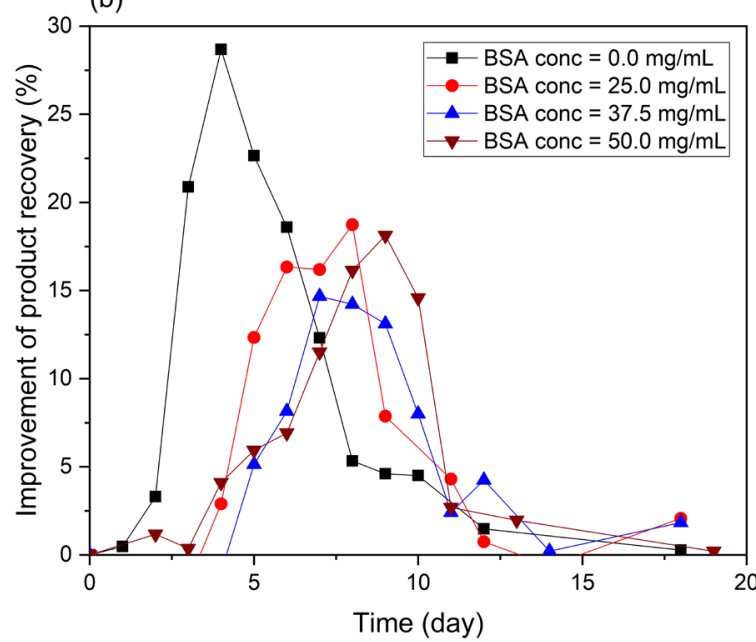

Fig. 7. (a) Phase diagram of lysozyme on day 4 and (b) improvement of product recovery with silica nanoparticle against unseeded cases with lysozyme initial concentration of $15.0 \mathrm{mg} / \mathrm{mL}$.

Fig. $7 \mathrm{~b}$ demonstrates an interesting general aspect about the use of silica nanoparticles and other heterogeneous nucleant: the "usefulness" of nucleant (i.e. quantitatively the improvement of product recovery over the case without nanoparticles) has a monomodal peak shape over time, which means there is an optimised cycle time for the crystallisation process. In this study, as the nanoparticles improved only the crystallisation kinetics, but had no effect on the solubility, the "usefulness" of nanoparticles diminished in the long run when the system came to equilibrium. Depending on the experimental conditions, the system can have a relatively long latent period in the presence of nanoparticles, making them not useful at the beginning of the process. For example, for BSA concentration $=25.0 \mathrm{mg} / \mathrm{mL}$ (Fig. $7 \mathrm{~b}$ ), the nanoparticles only started to crystallise out more lysozyme than the control case on day 4 and the improvement reached the highest value $(19 \%)$ on day 8 before a sharp decrease due to the rapid crystallisation in the control case.

As the experimental $\mathrm{pH}$ (4.6) was between the pl of silica nanoparticle and lysozyme (2.0 and 11.1 respectively as shown in Table 1 ), these two materials were oppositely charged. The positive effect of silica nanoparticle on lysozyme crystallisation most likely originated from the adsorption of lysozyme on silica nanoparticles via electrostatic attraction, as previous studies showed that lysozyme could adsorb on the nanoparticle surface in multiple layers [61,62]. Although some previous studies also showed that $\mathrm{pH}$ close to the $\mathrm{pl}$ of BSA promoted the adsorption of BSA molecules on silica $[63,64]$, the silica nanoparticle surface was predominantly occupied by lysozyme molecules through competitive adsorption in this study. Otherwise, significant adsorption of BSA on silica nanoparticle would have nullified the enhancement effect of crystallisation.

With their high local density of lysozyme molecules, these layers served as the nucleation sites (Fig. 8), probably through the re-organisation of the adsorbed molecules to form two-dimensional surface crystals $[39,65]$. The agglomeration of silica nanoparticles due to high protein concentration and ionic strength further enhanced the success of nucleation on the surface of silica nanoparticles as the adsorbed lysozyme molecules were brought even closer together via nanoparticle agglomeration [66]. 

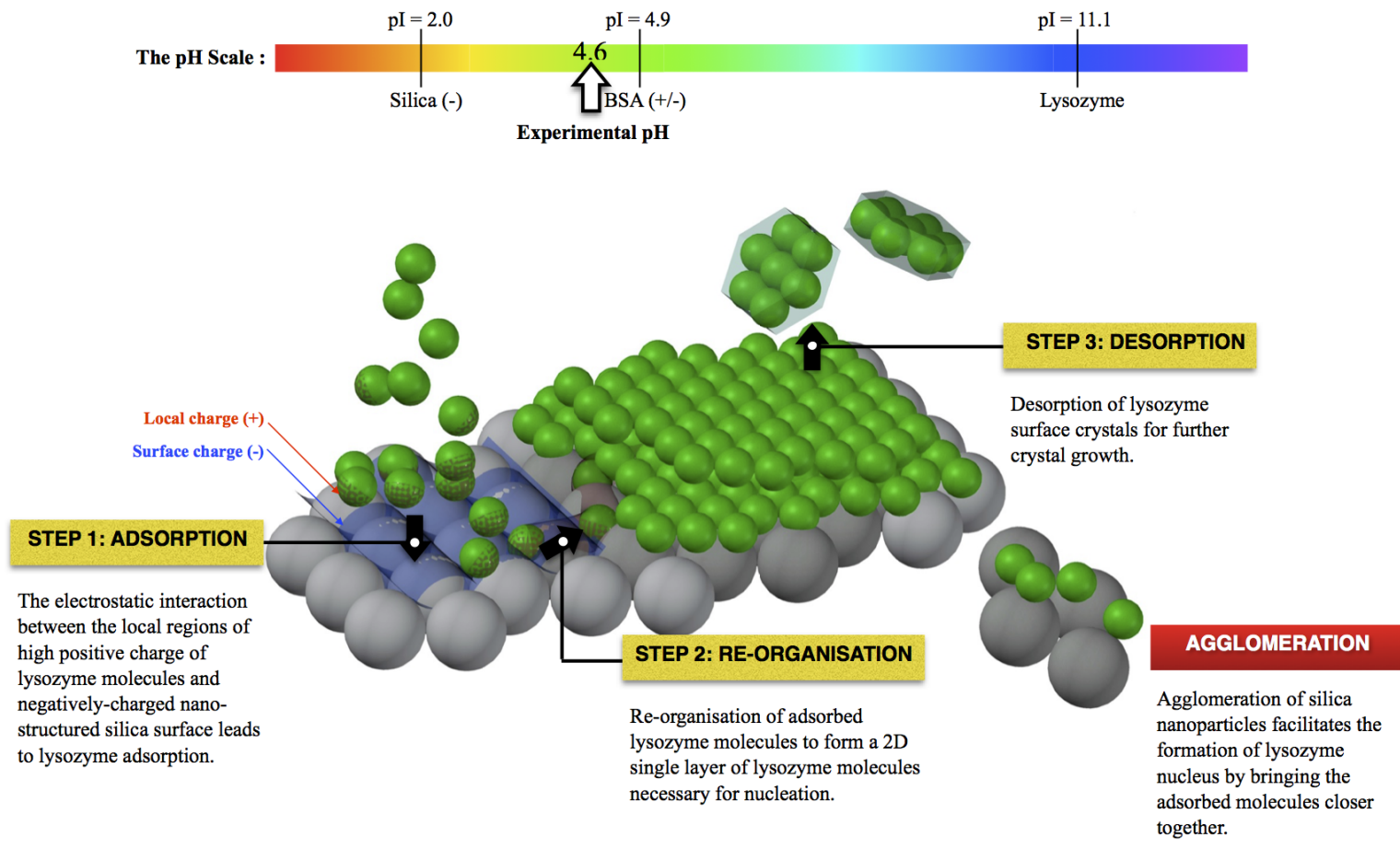

Lysozyme molecule

Silica nanoparticle

Fig. 8. Enhancement of lysozyme nucleation by silica nanoparticle through adsorption.

\section{Conclusions}

This study successfully demonstrated the adverse impacts of protein impurities on the crystallisation of target protein using the lysozyme-BSA system and the effectiveness of silica nanoparticle in promoting the crystallisation of target protein against impurity. As the model protein impurity, BSA increased the solubility of lysozyme, leading to slower crystallisation kinetics and lower product recovery at equilibrium. The application of silica nanoparticle achieved significant improvement of crystallisation kinetics for lysozyme across the entire range of BSA concentration $(0.0-50.0 \mathrm{mg} / \mathrm{mL})$ at $1 \mathrm{~mL}$ scale. The improvement of crystallisation kinetics originated from the adsorption of lysozyme onto silica nanoparticles due to electrostatic attraction as both materials were oppositely charged at the experimental $\mathrm{pH}$ of 4.6 , whereas BSA $(\mathrm{pl}=4.9)$ was relatively neutral. As the current study demonstrates the technical feasibility of nanoparticle-enhanced crystallisation for biopurification, more future studies on the scale-up of protein crystallisation with the help of other heterogeneous nucleants should be conducted to further develop this approach as an efficient purification technology for therapeutic proteins in general.

\section{Acknowledgement}

The financial support of this work comes from the SCoBiC project which is funded by the UK's EPSRC (EP/N015916/1). 


\section{Declaration of Competing Interest}

The authors declare that they have no known competing financial interests or personal relationships that could have appeared to influence the work reported in this paper. 


\section{References}

[1] D.M. Ecker, S.D. Jones, H.L. Levine, The therapeutic monoclonal antibody market, MAbs. 7 (2015) 9-14.

[2] B. Kelley, Industrialization of mAb production technology: The bioprocessing industry at a crossroads, MAbs. 1 (2009) 440-449.

[3] G. Feng, D. Hu, L. Yang, Y. Cui, X.A. Cui, H. Li, Immobilized-metal affinity chromatography adsorbent with paramagnetism and its application in purification of histidine-tagged proteins, Sep. Purif. Technol. (2010).

[4] F.C. Chong, W.S. Tan, D.R.A. Biak, T.C. Ling, B.T. Tey, A preparative hydrophobic interaction chromatography for purification of recombinant nucleocapsid protein of Nipah virus from clarified Escherichia coli homogenate, Sep. Purif. Technol. (2010).

[5] F. Geng, Q. Huang, X. Wu, G. Ren, Y. Shan, G. Jin, M. Ma, Co-purification of chicken egg white proteins using polyethylene glycol precipitation and anion-exchange chromatography, Sep. Purif. Technol. (2012).

[6] A.A. Shukla, L.S. Wolfe, S.S. Mostafa, C. Norman, Evolving trends in mAb production processes, Bioeng. Transl. Med. 2 (2017) 58-69.

[7] U. Gottschalk, Bioseparation in antibody manufacturing: The good, the bad and the ugly, Biotechnol. Prog. 24 (2008) 496-503.

[8] Z. Elgundi, M. Reslan, E. Cruz, V. Sifniotis, V. Kayser, The state-of-play and future of antibody therapeutics, Adv. Drug Deliv. Rev. 122 (2017) 2-19.

[9] R. O'Kennedy, C. Murphy, T. Devine, Technology advancements in antibody purification, Antib. Technol. J. 6 (2016) 17-32.

[10] A. Navarro, H.S. Wu, S.S. Wang, Engineering problems in protein crystallization, Sep. Purif. Technol. (2009).

[11] W. Chen, S.J. Park, F. Kong, X. Li, H. Yang, J.Y.Y. Heng, High protein-loading silica template for heterogeneous protein crystallisation, Cryst. Growth Des. 20 (2020) 866-873.

[12] H. Yang, P. Peczulis, P. Inguva, X. Li, J.Y.Y. Heng, Continuous protein crystallisation platform and process: Case of lysozyme, Chem. Eng. Res. Des. 136 (2018) 529-535.

[13] M.M. Roberts, J.Y.Y. Heng, D.R. Williams, Protein crystallization by forced flow through glass capillaries: Enhanced lysozyme crystal growth, Cryst. Growth Des. 10 (2010) 1074-1083.

[14] U. V. Shah, C. Amberg, Y. Diao, Z. Yang, J.Y.Y. Heng, Heterogeneous nucleants for crystallogenesis and bioseparation, Curr. Opin. Chem. Eng. 8 (2015) 69-75.

[15] X. He, R. Chen, X. Zhu, Q. Liao, S. Li, Laser assisted microfluidic membrane evaporator for sample crystallization separation, Sep. Purif. Technol. (2020).

[16] Z. Ding, S. Li, X. Cao, Separation of lysozyme from salted duck egg white by affinity precipitation using pH-responsive polymer with an L-thyroxin ligand, Sep. Purif. Technol. (2014).

[17] K.J. Hwang, H.C. Hwang, The purification of protein in cross-flow microfiltration of microbe/protein mixtures, Sep. Purif. Technol. (2006).

[18] Y. Wan, J. Lu, Z. Cui, Separation of lysozyme from chicken egg white using ultrafiltration, Sep. Purif. Technol. (2006). 
[19] N. Alele, M. Ulbricht, Membrane-based purification of proteins from nanoparticle dispersions: Influences of membrane type and ultrafiltration conditions, Sep. Purif. Technol. (2016).

[20] K.W. Chew, S.R. Chia, S.Y. Lee, L. Zhu, P.L. Show, Enhanced microalgal protein extraction and purification using sustainable microwave-assisted multiphase partitioning technique, Chem. Eng. J. 367 (2019) 1-8.

[21] F.A. Van Winssen, J. Merz, L.M. Czerwonka, G. Schembecker, T. Dortmund, Application of the Tunable Aqueous Polymer-Phase Impregnated Resins-Technology for protein purification, Sep. Purif. Technol. (2014).

[22] G. Ren, X. Gong, B. Wang, Y. Chen, J. Huang, Affinity ionic liquids for the rapid liquid-liquid extraction purification of hexahistidine tagged proteins, Sep. Purif. Technol. (2015).

[23] S.C. Lo, R.N. Ramanan, B.T. Tey, W.S. Tan, P.L. Show, T.C. Ling, C.W. Ooi, Purification of the recombinant enhanced green fluorescent protein from Escherichia coli using alcohol + salt aqueous two-phase systems, Sep. Purif. Technol. (2018).

[24] L.S. Castro, P. Pereira, L.A. Passarinha, M.G. Freire, A.Q. Pedro, Enhanced performance of polymer-polymer aqueous two-phase systems using ionic liquids as adjuvants towards the purification of recombinant proteins, Sep. Purif. Technol. (2020).

[25] D.C.V. Belchior, M. V. Quental, M.M. Pereira, C.M.N. Mendonça, I.F. Duarte, M.G. Freire, Performance of tetraalkylammonium-based ionic liquids as constituents of aqueous biphasic systems in the extraction of ovalbumin and lysozyme, Sep. Purif. Technol. (2020).

[26] H.F. Liu, J. Ma, C. Winter, R. Bayer, Recovery and purification process development for monoclonal antibody production, MAbs. 2 (2010) 480-499.

[27] D. Hebel, S. Huber, B. Stanislawski, D. Hekmat, Stirred batch crystallization of a therapeutic antibody fragment, J. Biotechnol. 166 (2013) 206-211.

[28] J. Brange, A. Vølund, Insulin analogs with improved pharmacokinetic profiles, Adv. Drug Deliv. Rev. 35 (1999) 307-335.

[29] M.X. Yang, B. Shenoy, M. Disttler, R. Patel, M. McGrath, S. Pechenov, A.L. Margolin, Crystalline monoclonal antibodies for subcutaneous delivery., Proc. Natl. Acad. Sci. U. S. A. 100 (2003) 6934-9.

[30] B. Shenoy, Y. Wang, W. Shan, A.L. Margolin, Stability of crystalline proteins, Biotechnol. Bioeng. 73 (2001) 358-369.

[31] W. Chen, H. Yang, J.Y.Y. Heng, Continuous Protein Crystallization, in: Handb. Contin. Cryst., 2020: pp. 372-392.

[32] D. Hekmat, M. Huber, C. Lohse, N. Von Den Eichen, D. Weuster-Botz, Continuous Crystallization of Proteins in a Stirred Classified Product Removal Tank with a Tubular Reactor in Bypass, Cryst. Growth Des. 17 (2017) 4162-4169.

[33] A. McPherson, P. Shlichta, Heterogeneous and epitaxial nucleation of protein crystals on mineral surfaces, Science (80-. ). 239 (1988) 385-387.

[34] F. Hodzhaoglu, F. Kurniawan, V. Mirsky, C. Nanev, Gold nanoparticles induce protein crystallization, Cryst. Res. Technol. 43 (2008) 588-593.

[35] E. Curcio, E. Fontananova, G. Di Profio, E. Drioli, Influence of the structural properties of poly(vinylidene fluoride) membranes on the heterogeneous nucleation rate of protein crystals, J. Phys. Chem. B. 110 (2006) 12438-12445. 
[36] D.G. Georgieva, M.E. Kuil, T.H. Oosterkamp, H.W. Zandbergen, J.P. Abrahams, Heterogeneous nucleation of three-dimensional protein nanocrystals, Acta Crystallogr. Sect. D Biol. Crystallogr. 63 (2007) 564-570.

[37] M. Sugahara, Y. Asada, Y. Morikawa, Y. Kageyama, N. Kunishima, Nucleant-mediated protein crystallization with the application of microporous synthetic zeolites, Acta Crystallogr. Sect. D Biol. Crystallogr. 64 (2008) 686-695.

[38] A. Sengupta Ghatak, A. Ghatak, Disordered nanowrinkle substrates for inducing crystallization over a wide range of concentration of protein and precipitant, Langmuir. 29 (2013) 43734380.

[39] S.A. Hemming, A. Bochkarev, S.A. Darst, R.D. Kornberg, P. Ala, D.S.C. Yang, A.M. Edwards, The Mechanism of Protein Crystal Growth from Lipid Layers, J. Mol. Biol. 246 (1995) 308-316.

[40] K. Ino, I. Udagawa, K. Iwabata, Y. Takakusagi, M. Kubota, K. Kurosaka, K. Arai, Y. Seki, M. Nogawa, T. Tsunoda, F. Mizukami, H. Taguchi, K. Sakaguchi, Heterogeneous nucleation of protein crystals on fluorinated layered silicate, PLoS One. 6 (2011) e22582.

[41] H. Yang, W. Chen, P. Peczulis, J.Y.Y. Heng, Development and Workflow of a Continuous Protein Crystallization Process: A Case of Lysozyme, Cryst. Growth Des. (2019).

[42] D. Hekmat, Large-scale crystallization of proteins for purification and formulation, Bioprocess Biosyst. Eng. 38 (2015) 1209-1231.

[43] J. V. Parambil, M. Schaepertoens, D.R. Williams, J.Y.Y. Heng, Effects of oscillatory flow on the nucleation and crystallization of insulin, Cryst. Growth Des. 11 (2011) 4353-4359.

[44] W. Stöber, A. Fink, E. Bohn, Controlled growth of monodisperse silica spheres in the micron size range, J. Colloid Interface Sci. 26 (1968) 62-69.

[45] G.H. Bogush, M.A. Tracy, C.F. Zukoski IV, Preparation of monodisperse silica particles: Control of size and mass fraction, J. Non. Cryst. Solids. 104 (1988) 95-106.

[46] Y.U. Moon, R.A. Curtis, C.O. Anderson, H.W. Blanch, J.M. Prausnitz, Protein-protein interactions in aqueous ammonium sulfate solutions. Lysozyme and bovine serum albumin (BSA), J. Solution Chem. 29 (2000) 699-718.

[47] B. Lorber, M. Skouri, J.P. Munch, R. Giegé, The influence of impurities on protein crystallization; the case of lysozyme, J. Cryst. Growth. 128 (1993) 1203-1211.

[48] X. Chen, Y. Ji, J. Wang, Improvement on the crystallization of lysozyme in the presence of hydrophilic ionic liquid, Analyst. 135 (2010) 2241-2248.

[49] T. Peters, Serum Albumin, Adv. Protein Chem. 37 (1985) 161-245.

[50] I. Marini, R. Moschini, A. Del Corso, U. Mura, Chaperone-like features of bovine serum albumin: A comparison with $\alpha$-crystallin, Cell. Mol. Life Sci. 62 (2005) 3092-3099.

[51] T.E. Finn, A.C. Nunez, M. Sunde, S.B. Easterbrook-Smith, Serum albumin prevents protein aggregation and amyloid formation and retains chaperone-like activity in the presence of physiological ligands, J. Biol. Chem. 287 (2012) 21530-21540.

[52] G.J. van der Vusse, Albumin as fatty acid transporter, in: Drug Metab. Pharmacokinet., 2009.

[53] C.A. Teske, H.W. Blanch, J.M. Prausnitz, Chromatographic measurement of interactions between unlike proteins, Fluid Phase Equilib. 219 (2004) 139-148.

[54] P.M. Tessier, S.I. Sandler, A.M. Lenhoff, Direct measurement of protein osmotic second virial 
cross coefficients by cross-interaction chromatography, Protein Sci. 13 (2004) 1379-1390.

[55] P. Lijnzaad, H.J.C. Berendsen, P. Argos, A method for detecting hydrophobic patches on protein surfaces, Proteins Struct. Funct. Genet. (1996).

[56] H. Shirahama, J. Lyklema, W. Norde, Comparative protein adsorption in model systems, J. Colloid Interface Sci. 139 (1990) 177-187.

[57] Y.I. Tarasevich, Interaction of globular albumins with the silica surface, Theor. Exp. Chem. 37 (2001) 98-102.

[58] M.M. Lynch, J. Liu, M. Nigra, M.O. Coppens, Chaperonin-Inspired pH Protection by Mesoporous Silica SBA-15 on Myoglobin and Lysozyme, Langmuir. 32 (2016) 9604-9610.

[59] A. Adawy, E. Rebuffet, S. Törnroth-Horsefield, W.J. De Grip, W.J.P. Van Enckevort, E. Vlieg, High resolution protein crystals using an efficient convection-free geometry, Cryst. Growth Des. 13 (2013) 775-781.

[60] V. Bhamidi, B.L. Hanson, A. Edmundson, E. Skrzypczak-Jankun, C. Schall, Influence of a homologous protein impurity on lysozyme crystal growth, J. Cryst. Growth. 204 (1999) 542552.

[61] A.A. Vertegel, R.W. Siegel, J.S. Dordick, Silica nanoparticle size influences the structure and enzymatic activity of adsorbed lysozyme, Langmuir. 20 (2004) 6800-6807.

[62] T.J. Su, J.R. Lu, R.K. Thomas, Z.F. Cui, J. Penfold, The adsorption of lysozyme at the silica-water interface: A neutron reflection study, J. Colloid Interface Sci. 203 (1998) 419-429.

[63] T.J. Su, J.R. Lu, R.K. Thomas, Z.F. Cui, J. Penfold, The conformational structure of bovine serum albumin layers adsorbed at the silica-water interface, J. Phys. Chem. B. 102 (1998) 8100-8108.

[64] T.J. Su, J.R. Lu, R.K. Thomas, Z.F. Cui, Effect of $\mathrm{pH}$ on the adsorption of bovine serum albumin at the silica/water interface studied by neutron reflection, J. Phys. Chem. B. 103 (1999) 37273736.

[65] J. Malkin, Y.G. Kuznetsov, T.A. Land, J.J. Deyoreo, A. McPherson, Mechanisms of growth for protein and virus crystals, Nat. Struct. Biol. 2 (1995) 956-959.

[66] U. Weichsel, D. Segets, T. Thajudeen, E.M. Maier, W. Peukert, Enhanced Crystallization of Lysozyme Mediated by the Aggregation of Inorganic Seed Particles, Cryst. Growth Des. 17 (2017) 967-981. 